\title{
THE BUOYANCY OF BATHYPELAGIC FISHES WITHOUT A GAS-FILLED SWIMBLADDER
}

\author{
By E. J. Denton \\ The Plymouth Laboratory \\ and N. B. Marshall \\ British Museum (Natural History) \\ (Plates I and II, and Text-figs. I-3) \\ INTRODUCTION
}

The upper reaches of the deep ocean contain many bathypelagic fishes with a capacious, gas-filled swimbladder. But living within and below this region are also numerous species in which this hydrostatic organ is absent or markedly regressed (Marshall, in preparation). In the neritic province nearly all the fishes that swim freely at the various water levels (and can stay poised at a particular level without undue effort) have a well-developed swimbladder, the capacity of which is about equal to $5 \%$ of the body volume (Jones \& Marshall, I953). Having this amount of gas, these fishes are able to keep their weight in water close to the vanishing point. If such a fish were deprived of its swimbladder, it could keep at a constant level only by exerting a downward force equivalent to $5 \%$ of its weight in air. The swimbladder thus saves the fish the energy needed for such effort, which is quite appreciable.

The advantage to a fish of being in neutral buoyancy can be illustrated by the following simple calculations. A fish deprived of the gas in its swimbladder would have a reduced weight in water of $5-8 \%$ of its weight in air (depending on whether it were a a marine or freshwater fish). To stay at constant level it would have to exert a downward force equal to its reduced weight (and unlike terrestrial animals, pelagic creatures only exert forces on the surrounding medium by making movements). When it is remembered that even an active pelagic fish seldom exerts a force of more than $25-50 \%$ of its weight in air for more than a very brief period (Gray, I953), the force necessary for a fish to maintain its level appears to be considerable.

How considerable an economy the swimbladder allows can be further evaluated by realizing that the drag of the water opposing a fish's movement is proportional to (velocity) ${ }^{\frac{2}{2}}$ for laminar flow and approximately (velocity) ${ }^{2}$ for turbulent flow (Kermack, 1948; Hill, I950). Thus for some active pelagic fish a force of $7 \%$ of the body weight would enable a fish to sustain continuously a horizontal velocity of $43 \%$ or $53 \%$ (depending on whether the flow is laminar or turbulent) of that velocity which it would have if it exerted continuously a force of $25 \%$ of its body weight, a force fishes seldom exert. (If we take our reference velocity as that given by a fish exerting $50 \%$ of its body weight then $7 \%$ would give a sustained velocity of $27 \%$ or $37 \%$ of this velocity). The above calculations were made by E. J. Denton and T. I. Shaw. 
The mackerel (Scomber scombrus) is one of the few freely swimming fishes from the neritic region without a swimbladder, and it is noticeable that it can only maintain its level in the water by restless and vigorous activity. This unceasing motion is perhaps the price paid for a facility of moving up and down quickly in the top layers of the sea; for to come quickly to the surface from $20 \mathrm{~m}$ would increase the volume of a swimbladder threefold, and, apart from the danger of internal damage, the fish would have to exert an upward force equal to about $10 \%$ of its weight in order to go down again. ${ }^{1}$.

The $5 \%$ relation between the swimbladder and body volume is also found in bathypelagic teleosts (Kanwisher \& Ebeling, 1957). This might suggest that the species without a swimbladder were faced with the same problems as the mackerel. But many of these fishes have fragile, lightly ossified skeletons, the scales are reduced or absent, and the muscle layers of the trunk and tail are thin. This must lead to some reduction of their weight in water and it has been suggested (Marshall, 1954, 1955) that they are not much heavier than their surroundings. Measurements by one of us (E.J.D) have shown this is certainly true of two fairly common bathypelagic fishes without a swimbladder, Gonostoma elongatum (order Isospondyli, suborder Stomiatoidea) and Xenodermichthys copei (order Isospondyli, suborder Clupeoidea). Analysis of their chemical composition has revealed how this reduction of specific gravity is achieved. However, in evading, or almost evading, the buoyancy problem, it is the muscles used in propulsion that are particularly reduced. Nevertheless, the proportion of muscle (as indicated by total protein) falls less than does the downward force which has to be exerted to keep the fish in a given horizontal plane. Because of loss of speed, this might, however, seem to be like 'jumping from the frying pan into the fire', but consideration of the biology and environment of the bathypelagic fishes without a swimbladder reveals much of how this problem seems to have been met.

\section{MATERIAL AND METHODS}

The buoyancy of the fish

These experiments were made in the Bay of Biscay aboard R.V. 'Sarsia'. The deep-sea fish were caught in an Isaacs-Kidd mid-water trawl, the live fish being put into sea water previously cooled to about $10^{\circ} \mathrm{C}$. A piece of cotton was threaded through the lower jaw of a fish and the fish was weighed in air on a roo g spring balance, and in sea water using a torsion balance of I $g$ full-scale deflexion. The torsion balance was on a gimbal table and it proved possible to measure the weight of the fish in sea water to a few milli-

\footnotetext{
1 Dr G. Hughes (private communication) has noted that a considerable fraction of a fish's metabolism may be devoted to providing the flow of water across the gills. A fish like a mackerel which uses its forward motion to provide much of this flow may not be at such a disadvantage as simple calculation might suggest.
} 
grams. Great care was taken for the weighing under sea water to have no bubbles of air on or inside the deep-sea fish and both spring balance and torsion balance were frequently checked with known weights. After checking the weight in sea water several times the fish was taken out of sea water, gently dried and placed in a dry honey jar or Kilner jar and stored in a deepfreeze. Before using the fish for chemical analysis the jar and fish were weighed and after removing the fish and drying the jar this was weighed alone. The difference between these two weights gave a check on the accuracy of the weighing of the fish which had been made at sea. At sea the temperature of the sea water used was noted and samples of the sea water were taken in sealed jars. The specific gravities of the samples were measured with a hydrometer on returning to Plymouth.

The common bathypelagic fish Chauliodus sloanei has a thick transparent gelatinous envelope around its body. It was thought that this might be less dense than sea water and thus provide some positive buoyancy. Pieces of this material cut away from the fish were, however, found to be heavier than sea water.

Direct measurements were made of the contribution of the swimbladder gases to the buoyancy of the coastal fish Ctenolabrus rupestris. Specimens of this fish, freshly killed, were weighed in air and in sea water after opening the fish, puncturing the swimbladder and squeezing out its gas. These measurements showed that such a fish without the gas in its swimbladder would have a weight in sea water of about $5.4 \%$ of its weight in air. This weight must in very large part be attributed to the muscles (the largest single tissue component), for isolated pieces of muscle had in sea water about $5 \%$ of their weight in air. Experiments on coastal fish of different species showed that the density of muscle varies appreciably; the weight of hake (Merluccius merluccius) muscle in sea water was only $3.2 \%$ of its weight in air. These experiments suggested that a variation in the proportion of protein might be an important variable in the 'buoyancy balance sheet' of fishes. That this is so was borne out by the determinations of chemical composition described below.

\section{Chemical analysis}

The chemical analyses were made with the advice and help of $\mathrm{Mr}$ E. I. Butler. Not all fishes were analysed in the same way but the most complete analyses were made in the following way:

The fish were ground with sand and anhydrous calcium sulphate and Soxhlet extracted with $40^{\circ}-60^{\circ}$ petroleum ether. The residue was reground and dried in an oven for several hours when further extracts were made until no further material could be extracted. The residue, insoluble in petroleum ether, was extracted in a Soxhlet apparatus with $96 \%$ alcohol to constant weight of extract. The nitrogen in the final residue was estimated, and the alcohol extract refluxed with $40^{\circ}-60^{\circ}$ petroleum ether and filtered. The filtrate contained only that fraction of the animal's fat which was extractable by 
alcohol but not petroleum ether and this was estimated by drying the filtrate to constant weight. The alcohol-soluble ether-insoluble nitrogen was estimated using the method of Kjeldahl.

As a check on this method the procedure was varied. On occasions total nitrogen was estimated using whole fish, whilst on other occasions the fat was extracted after grinding with sand fish which had been oven dried $\left(105^{\circ} \mathrm{C}\right)$ to constant weight. The various methods used gave results which were in good agreement with one another. The dry weights given in this paper are those of fish cut into very small pieces and dried in an oven at $105^{\circ} \mathrm{C}$ to constant weight.

\section{RESULTS}

\section{The buoyancy of Gonostoma and Xenodermichthys}

All the fishes used were caught alive and in very good condition. The values for the (weight in sea water/weight in air) $\times$ Ioo were for, 6 Gonostoma $0.54,0.68,0.90,0.34,0.40,0.90$ (average 0.63 ) and for 6 Xenodermichthys $I \cdot 4, I \cdot I, I \cdot 4, I \cdot I, I \cdot 2, I \cdot 3$ (average I.25).

The sea water used for these buoyancy measurements was found to have a salinity close to that in which the fish live, i.e. about $35.5 \mathrm{~g}$ of salt in $1000 \mathrm{~g}$ of sea water. These fish are usually found down to $1000 \mathrm{~m}$ and, in the water of the Atlantic from which they were taken, there is little change in salinity between the surface and $1000 \mathrm{~m}$ (Cooper, 1952). The maximum error in the above figure for (weight in sea water/weight in air) which might be attributed to differences in salinity was 0.05 and this is disregarded.

\section{Radiographs}

The radiographs (Pls. I and II) show that the skeletons of Chauliodus, Gonostoma and Xenodermichthys are very poorly ossified in comparison with specimens of coastal fish Gadus minutus of comparable weight. The deep sea myctophid Diaphus rafinesquei which has a swimbladder is seen to have a skeleton as well ossified as that of a Ctenolabrus rupestris of about the same weight. Pl. II shows the remarkable difference in ossification between Gonostoma elongatum and Gonostoma denudatum both bathypelagic fish, the former without, and the latter with, a gas-filled swimbladder.

\section{EXPLANATION OF PLATES}

Plate I

Radiographs comparing the degree of ossification of (A) Chauliodus sloanei, (B) Gadus minutus, (C) Gonostoma elongatum, and (D) Gadus minutus. Of the two specimens of G. minutus the second (D) is much smaller than either of the bathypelagic fish. The swimbladders of $G$. minutus appear as light areas in the body. Magnification $\times \frac{4}{5}$.

\section{Plate II}

Radiographs (above) showing the difference in ossification between (A) Gonostoma bathyphilum and (B) G. elongatum; and (below) comparing the degree of ossification of (C) Ctenolabrus rupestris, (D) Diaphus rafinesquei, (E) Xenodermichthys copei, and (F) Gadus minutus. Magnification $\times \frac{4}{6}$. 


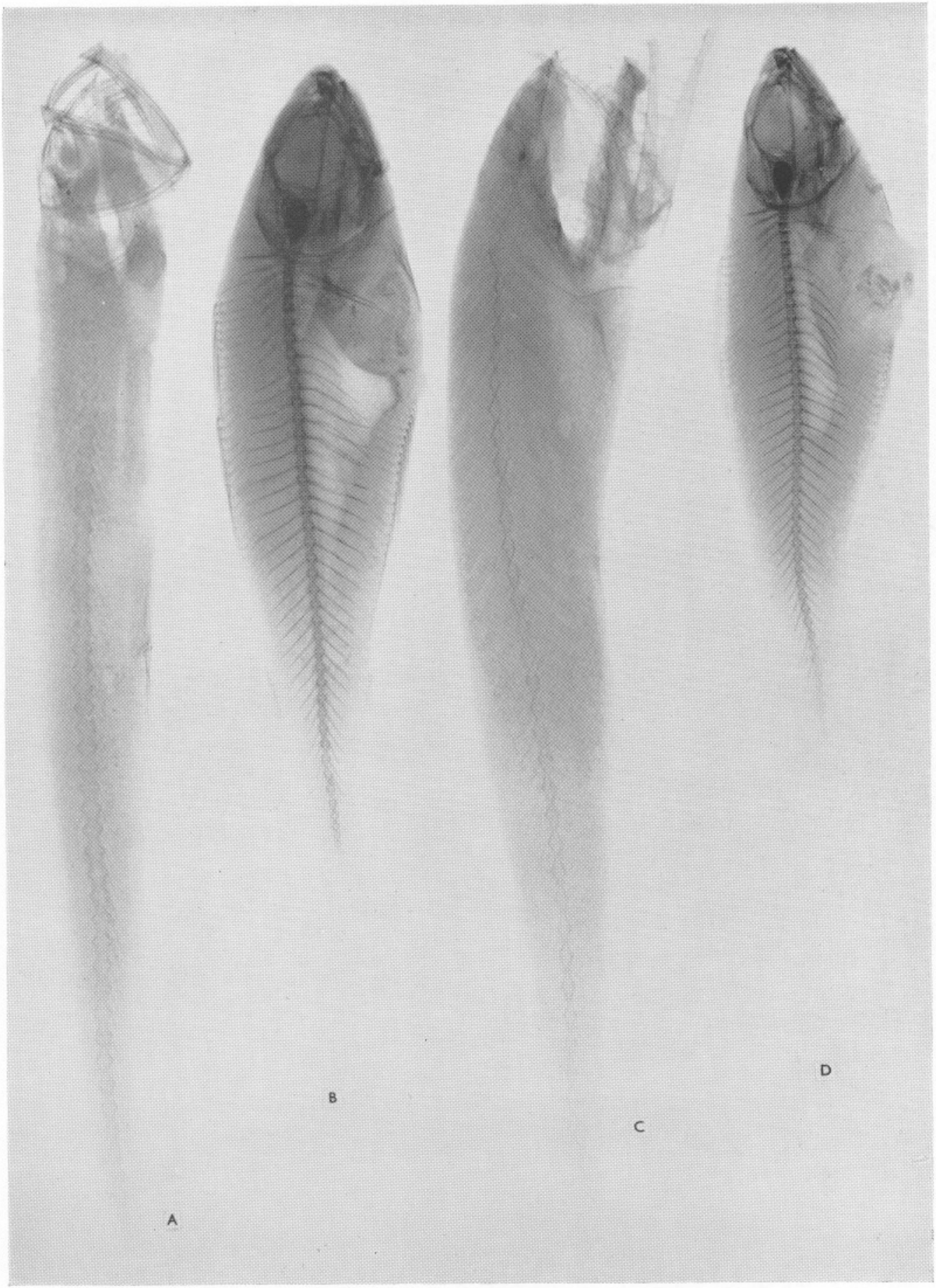

(Facing p. 756) 
A

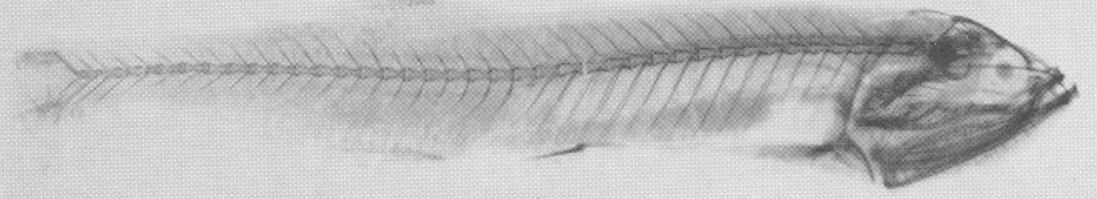

B

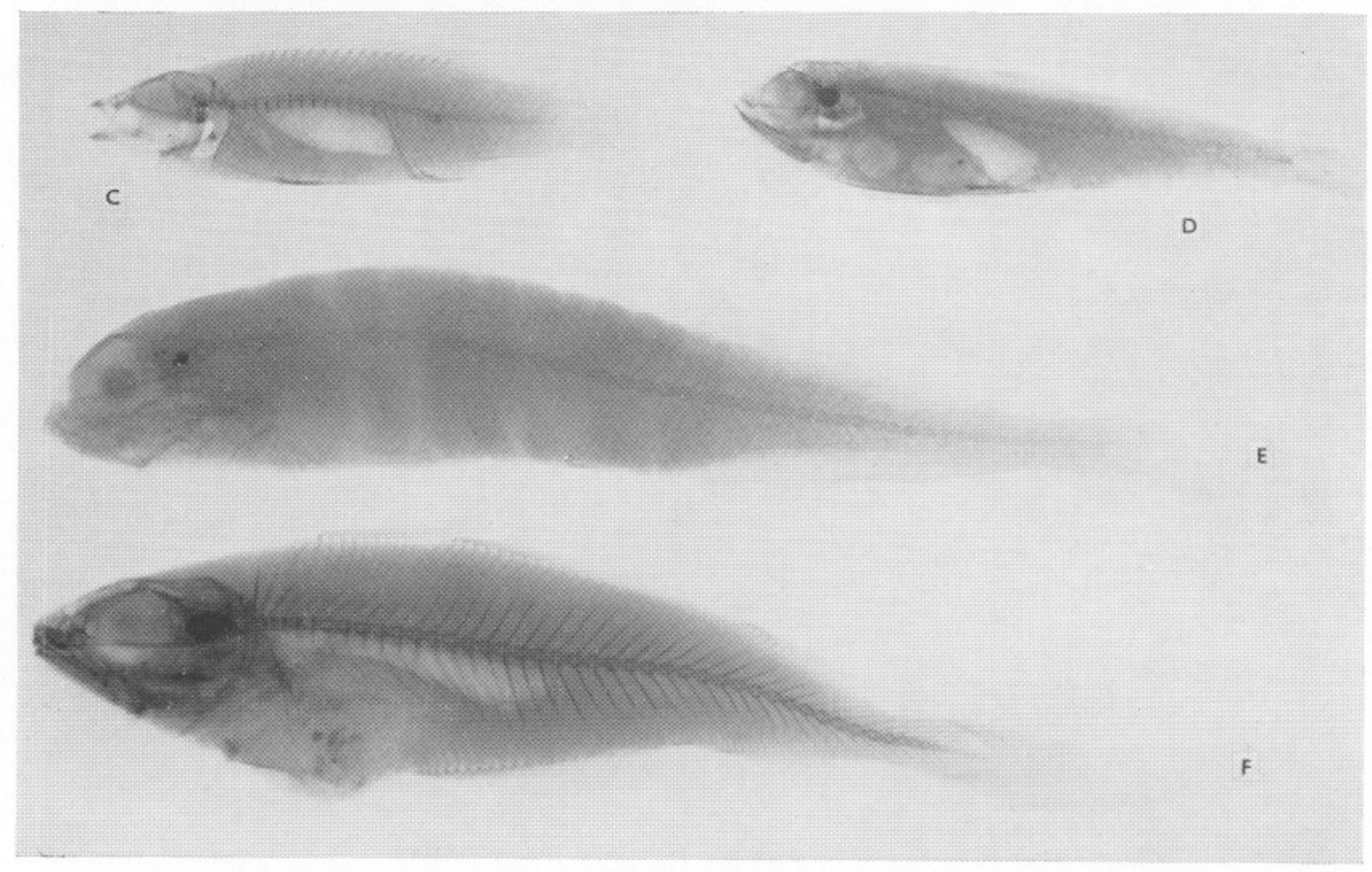


The otoliths of the bathypelagic fish without swimbladders are very small when compared with those of the fish with swimbladders. Particularly striking is the contrast between the large otoliths of the small fish Diaphus rafinesquei with the tiny otoliths of Chauliodus sloanei.

\section{Chemical analyses}

The principal results of the chemical analyses are given in Table I. Components are given as percentage of wet weight. The protein is taken as being $6.025 \times$ the total nitrogen (see Love, 1957).

TABLE 1. CHEMICAL ANALYSES

\begin{tabular}{|c|c|c|c|c|c|}
\hline Fish & $\begin{array}{l}\text { Fat } \\
\text { extractable } \\
\text { in } 40^{\circ}-60^{\circ} \\
\text { petroleum } \\
\text { ether }\end{array}$ & Total $\mathrm{N}_{2}$ & Protein & $\begin{array}{c}\text { Dry } \\
\text { weight }\end{array}$ & $\frac{\text { Wt. in sea water }}{\text { Wt. in air }} \times 100$ \\
\hline $\begin{array}{l}\text { Gonostoma } \\
\text { elongatum }\end{array}$ & 2.6 & - & - & - & 0.68 \\
\hline " & $5 \cdot 3$ & - & - & - & - \\
\hline \#* & $3 \cdot 4$ & $0.7 \mathrm{I}$ & $4 \cdot 3$ & $12 \cdot 6$ & $0.34,0.4$ \\
\hline ” & - & r.or & 6.0 & - & 0.54 \\
\hline , & - & 0.87 & $5 \cdot 2$ & - & - \\
\hline $\begin{array}{l}\text { Xenodermichthys } \\
\text { copei }\end{array}$ & 0.51 & - & - & - & - \\
\hline , & 0.55 & - & - & - & - \\
\hline ” & - & $1 \cdot 2$ & $7 \cdot 2$ & - & - \\
\hline " & - & - & - & $9 \cdot 8$ & - \\
\hline , * & - & $I \cdot 2$ & $7 \cdot 2$ & II & $I \cdot I, I \cdot 2$ \\
\hline $\begin{array}{l}\text { Ctenolabrus } \\
\text { rupestris }\end{array}$ & - & $2 \cdot 76$ & $16 \cdot 6$ & - & - \\
\hline , & - & - & - & 28 & - \\
\hline ” & - & - & - & 26 & - \\
\hline " & 0.5 & - & - & - & - \\
\hline Labrus bergylta $\dagger$ & - & $2 \cdot 72$ & $16 \cdot 4$ & - & - \\
\hline
\end{tabular}

Part of the lipid material in fish is bound in such a way as not to be extractable in petroleum ether. This is a small fraction of the total lipid in fish which have a good deal of fat but an important fraction when there is little fat (Lovern, 1955). After extracting with petroleum ether some fish were therefore further extracted with $96 \%$ alcohol to constant weight of extract. This alcohol was shaken with petroleum ether and the residue from the ether, after evaporation, was taken as the ether inextractable fat. Part of the total nitrogen of the fishes was non-protein nitrogen and this was estimated on the alcohol extract after shaking it with petroleum ether. For one Gonostoma the extra fat corresponded to $0.5 \%$ of the wet weight and for two Gonostoma the non-protein nitrogen to 0.05 and $0.04 \%$ of the wet weight. For Xenodermichthys the extra fat corresponded to $0.7 \%$ of the wet weight and the 
non-protein nitrogen to $0.04 \%$ of the wet weight. These are figures which would give only very small corrections and they are not taken into account in the Discussion below.

\section{Buoyancy properties}

\section{DISCUSSION}

The buoyancy measurements were made at around $10^{\circ} \mathrm{C}$ which is close to the normal environmental temperature for these fishes. They were left for some time in sea water at this temperature before the measurements were made.

The measurements were made in the laboratory on R.V: 'Sarsia' with the fish under sea water at atmospheric pressure, but the fish are often caught at depths around $500 \mathrm{~m}$ where they are subject to pressures of around 50 atmospheres. This change in pressure can, however, make very little difference to the buoyancy of the fish, for the change in volume of water when the pressure is raised from I to 50 atmospheres is only one of about $0.2 \%$ and the volume of the fish will change in much the same way as does the sea water, leaving a residual change in buoyancy which is only a small fraction of $0.2 \%$. We can therefore accept the surprising fact that Gonostoma is often within $\frac{1}{2} \%$ and Xenodermichthys within $\mathrm{I} \cdot 2 \%$ of neutral buoyancy despite the fact that neither fish has a gas-filled swimbladder.

The chemical analyses show quite clearly how this is achieved. These are extremely watery fishes with poorly ossified skeletons. The dry weight of Gonostoma and Xenodermichthys are only 12.5 and 10\% respectively of their weights, whereas the Ctenolabrus rupestris, used as a control, had a dry weight of about $28 \%$ of its wet weight. The fat content of the deep-sea fishes is not particularly high, averaging about $3 \%$, but the protein content of about $5 \%$ of their dry weight is very low indeed when compared with the corresponding $16 \%$ for the typical coastal fishes, Ctenolabrus rupestris and Labrus bergylta.

Most of the data in the literature is for edible portions of fish (see Vinogradov, I953, pp. 463-566). Shewan (I95I) gives total nitrogen figures varying from $2 \cdot 42$ to $3.78 \%$ for skeletal muscles of many teleosts. These values may be compared with the 2.76-2.74 given here for whole wrasse used for control experiments. The protein content of the principal organs of higher vertebrates is shown in the Handbook of Biological Data (1956) as varying from about 10 \% for brain and spinal cord through about $20 \%$ for skeletal muscle to $30 \%$ for skin.

Marine fishes normally derive a considerable degree of buoyancy from the fact that their body fluids are considerably more dilute than sea water. The figures given by Krogh (1939) for the extracellular fluids of marine teleosts suggest that these have an approximate osmotic pressure of about $40 \%$ that of sea water. The intracellular fluids will be in osmotic equilibrium with the extracellular fluids, although the components will be different. The principal 
intracellular cation is probably potassium rather than sodium (this in itself will affect the density little), and most of the anions will be organic compounds such as the organic phosphates of muscle and the haemoglobin of red blood cells whose contribution to density has to some extent been included in the organic analysis. The intracellular concentration of chloride will

TABLE 2. BALANCE SHEET FOR GONOSTOMA ELONGATUM

\begin{tabular}{lccc}
\multicolumn{1}{c}{ Component } & $\begin{array}{c}\text { W wet } \\
\text { weight }\end{array}$ & $\begin{array}{c}\text { Specific } \\
\text { gravity }\end{array}$ & $\begin{array}{c}\text { Weight in sea } \\
\text { water/Ioo g } \\
\text { of fish }\end{array}$ \\
Fat & $3 \cdot 7$ & $0.9 I^{\star}$ & -0.5 \\
Protein & $5 \cdot 0$ & $\mathrm{I} \cdot 33 \dagger$ & $+\mathrm{I} \cdot \mathrm{I}$ \\
Body fluids (water + dissolved salts) & 87.6 & $\mathrm{I} \cdot 0 \mathrm{I} 3$ & $-\mathrm{I} \cdot 2$ \\
Other components including bone & $3 \cdot 2 \ddagger$ & & $+\mathrm{I} \cdot \mathrm{I} \ddagger$
\end{tabular}

Buoyancy. These fish had no gas-filled swimbladder and their average weight in sea water was approximately $+0.5 \%$ of their weight in air. (Wet weight)

* Handbook of Biological Data (1956).

$\dagger$ Höber, (1954). Specific gravity taken as the reciprocal of the partial specific volume.

$\ddagger$ These values are given by difference.

\section{TABLE 3. BALANCE SHEET FOR CTENOLABRUS RUPESTRIS}

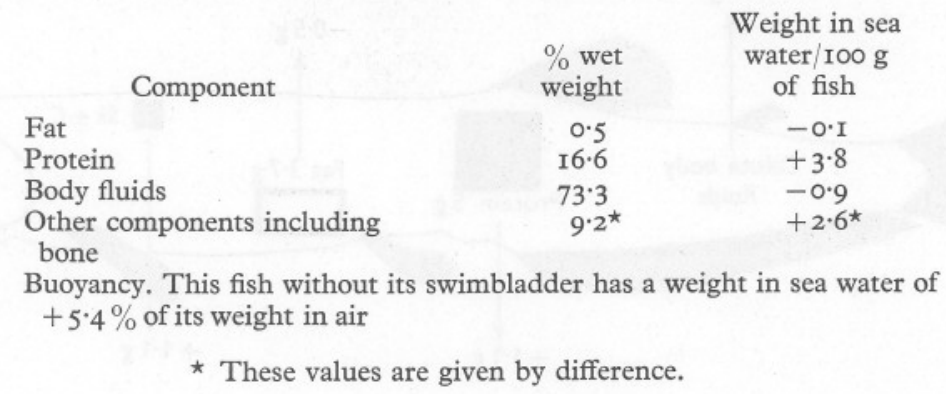

almost certainly be very much lower than the extracellular concentration. We will, however, in the absence of good analyses, make the assumption that both the deep-sea fish and the wrasse have body fluids whose density lies half way between that of distilled water and sea water. [Preliminary analyses indicate that this cannot (in terms of density) be very seriously in error.] It is now possible to draw up balance sheets to explain the buoyancy properties of a deep-sea fish and a wrasse (Text-fig. I, Tables 2 and 3 ). The negative weights imply that the component has a positive buoyancy in sea water.

Some idea of the contribution of the mineral components of bone is given by ashing the fish. Ashings in a platinum crucible of whole deep-sea fish (Xenodermichthys copei) gave for a high temperature (around $1000^{\circ} \mathrm{C}$ ) an 
ash of $\mathrm{I} \cdot 2 \%$ and for a low temperature (around $450^{\circ} \mathrm{C}$ ) an ash of $\mathrm{I} \cdot 9 \%$. The corresponding figures for ash from wrasse (Ctenolabrus rupestris) were both $4.5 \%$. The ash from wrasse contains large recognizable fragments; skull, vertebrae, etc., whilst that of the deep-sea fish is very much less in amount and much more powdery (Text-fig. 2). Some of the ash is sodium, potassium
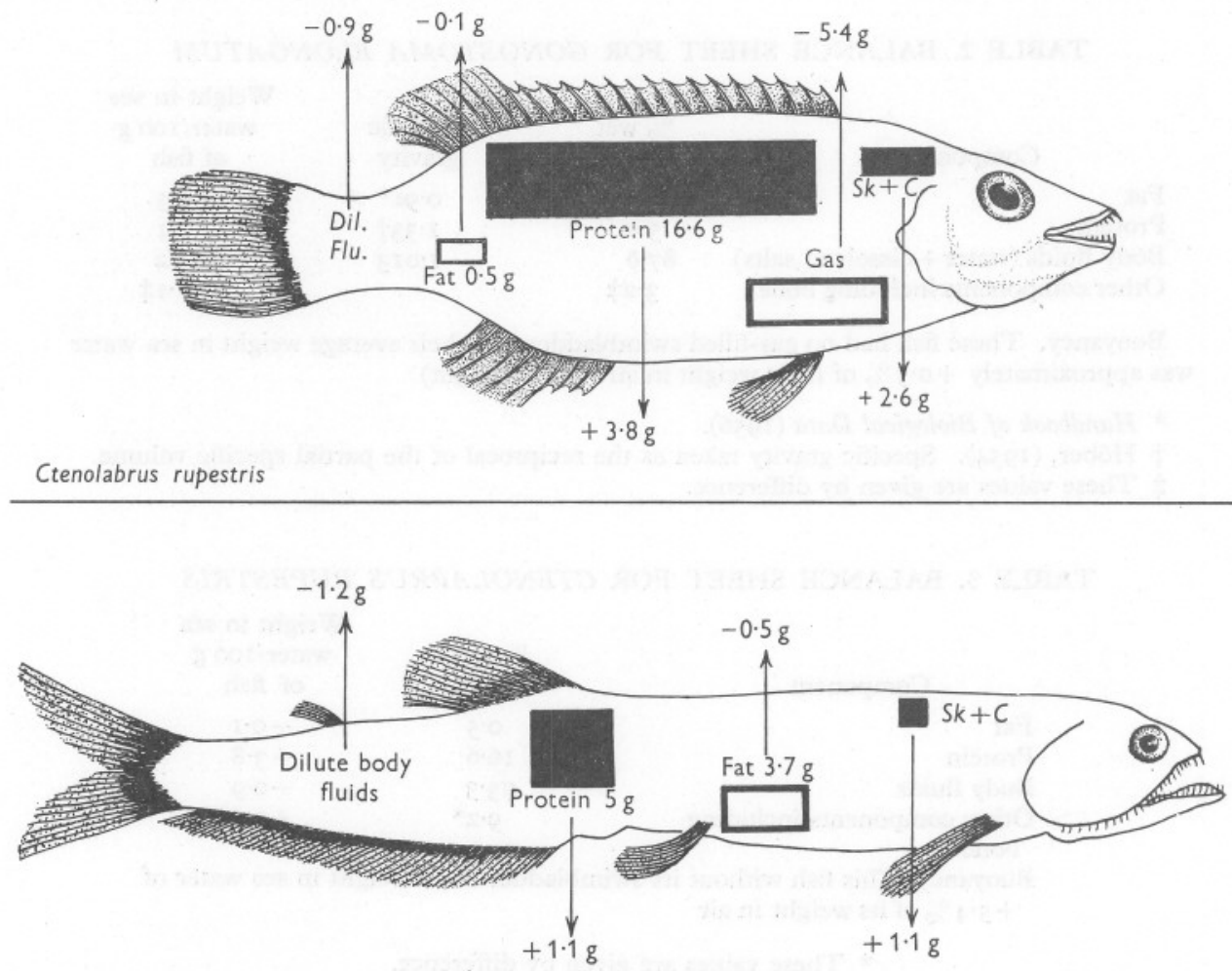

Gonostoma elongatum

Text-fig. I. Diagram of the 'buoyancy balance sheet' for a bathypelagic fish Gonostoma elongatum without a swimbladder (below) and a coastal fish Ctenolabrus rupestris with a swimbladder (above). Positive values are given for those components of the fish which are heavier than the sea water which they displace and thus tend to 'sink' the fish, whilst negative values are given for those components which displace more sea water than their own weight and thus tend to 'float' the fish. Weights given per $100 \mathrm{~g}$ of fish. Dil. Flu., dilute body fluids; $S k+C$, skeleton and other components.

and chloride. Estimates made of these components on water extracts from the ashes indicate that the remaining mineral components account for $\mathrm{I} \cdot 2 \%$ and $0.7 \%$ of the two deep-sea fish ashed. The densities of salts found in bone, e.g. apatite, (Harrow, 1954) are close to 3 (International Critical Tables, I928) so that the contribution of this material to the buoyancy of the 
fish will be about $+0.6 \mathrm{~g} / \mathrm{Io0} \mathrm{g}$ of fish for Xenodermichthys, which is a value rather smaller than that given in the above table on Gonostoma for 'other components including bone'.

\section{General biological considerations}

While these findings are striking in themselves, they may be seen in better perspective against a more general biological background.

Bathypelagic fishes without a gas-filled swimbladder are quite diverse. The main groups in the order Isospondyli are Melanostomiatidae, Stomiatidae,

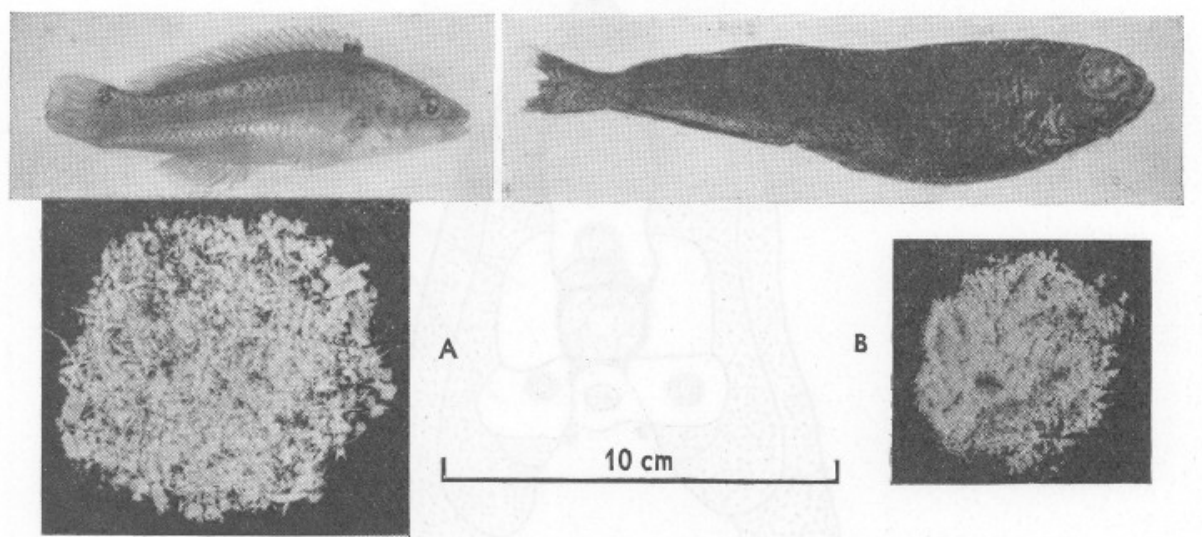

Text-fig. 2. A, a coastal fish with a swimbladder, Ctenolabrus rupestris, wet weight I6.7 g; with ash obtained from it shown below, weight $0.76 \mathrm{~g}$. B, a deep-sea fish without swimbladder, Xenodermichthys copei, wet weight $3 \mathrm{I} \cdot 2 \mathrm{~g}$; with ash obtained from it shown below, weight $0.33 \mathrm{~g}$.

Chauliodontidae, Idiacanthidae, Malacosteidae (stomiatoids), Alepocephalidae (clupeoids) and Bathylogidae (salmonoids). Of the order Iniomi, the entire suborder Alepisauroidea consists of fishes without any known trace of a gas-filled swimbladder at any stage of their life history (Marshall, 1955), and the same is true of the ceratioid angler-fishes (Bertelsen, 195I). Finally, there are the fishes of the small orders, Giganturoidea, Lyomeri, Cetunculi and Miripinnati, the last having a functional gas-filled swimbladder during the larval phase (Bertelsen \& Marshall, I956). These groups and a few not mentioned, make up nearly half of the bathypelagic fish fauna.

In these fishes the nature and extent of the tissues appear to be very similar to the two species we have analysed in detail. The stomiatoid species certainly have lightly ossified skeletons (the scales are absent or poorly developed) and a correspondingly reduced musculature. Concerning the melanostomiatids and Idiacanthus, Beebe \& Crane (1939) remark that ' . . . as usual in deep-sea fish, the jaws are the only really strongly ossified parts of the body, the gill 
arches usually come next, then the tip of the caudal penduncle, while the skull proper, the rest of the vertebral column and the supports of the vertical fins are ossified very late, and then usually weakly.'

These observations also apply to the alepisauroid fishes (Marshall, 1955) and particularly to the Lyomeri, which have a persistent notochord and a very reduced skeleton (Tchernavin, 1947). The weak lateral muscles in one species (Eurypharynx pelecanoides) is well shown in transverse sections figured by Nusbaum-Hilarowicz (1923). The vertebral column is not immediately surrounded by the myotomes, but by extensive fluid-filled cavities, which

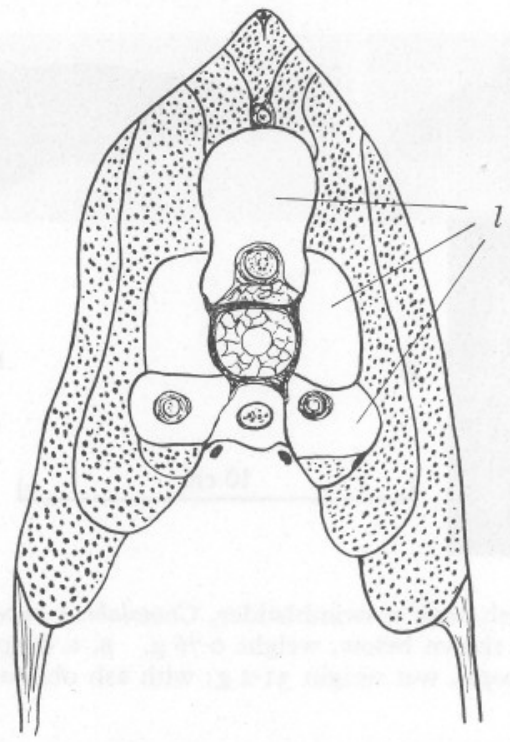

Text-fig. 3. Transverse section through the fore-part of the trunk of the gulper-eel, Eurypharynx pelecanoides, showing the extent of the muscle (dotted) and the lymphatic spaces $(l)$. (After Nusbaum-Hilarowicz, 1923).

appear to be lymphatic in nature (Text-fig. 3). The ceratioid angler-fishes also have weakly developed lateral muscles and lightly ossified skeleton (Bertelsen, I95I).

But, as we have already seen, such weakness of the skeletal and muscular systems is not true of bathypelagic fishes with capacious gas-filled swimbladders (for instance, the Myctophidae). Here we need only draw attention to the radiograph (Pl. II) of Gonostoma elongatum and G. denudatum. Earlier reference has been made to this (Marshall, 1954), but the plate gives more striking proof than words of the difference in ossification between these two related deep-sea fishes. The skeleton of G. denuidatum (the outline of the swimbladder can also be seen) stands out sharply beside that of G. elongatum, in which the swimbladder is regressed and invested with fat. (It should be 
stressed that both fish are of adult size and that this difference between them can also be readily appreciated when they are handled).

While the bathypelagic fishes with a well developed, gas-filled swimbladder tend to be concentrated at depths above $1000 \mathrm{~m}$, those lacking this organ are found at all mid-water levels known to contain fish. Of the groups listed above, most of the stomiatoids, bathylagids, alepisauroids, giganturoids and Miripinnati tend to occur above the $1000 \mathrm{~m}$ level, while the Lyomeri and ceratioid angler-fishes are mostly fished below this depth (for a review of the vertical distribution and references, see Marshall, (I954)). The latter seems to be also true of many alepocephalids, ${ }^{1}$ but not of such forms as Searsia (Grey, 1956).

Turning now to the physical nature of their environment, most species of bathypelagic fishes are found in the tropical and temperate regions of the ocean between depths of about $250 \mathrm{~m}$ down to at least $3000 \mathrm{~m}$. Owing to the rapid fall of temperature below the thermocline there is a corresponding increase in viscosity (between the above levels the laminar viscosity will be increased by a maximum factor of about $\mathrm{I} \cdot 66$ ). At the cooler, lower levels, a fish will thus gain more support from the surrounding water. If heavier than water it will sink more slowly, but it will find movements more difficult to make. At all events, it is interesting that the ceratioid angler-fishes, which appear to be little more than floating traps, make up most of the fish fauna at these lower levels.

Except for the Cetunculi and Miripinnati, which take small prey, particularly copepods (Bertelsen \& Marshall, 1956), most of the bathypelagic fishes without a swimbladder consume a wide range of food organisms. Considering only their larger prey, the stomiatioid groups, the alepisauroids (excluding the paralepidids), the giganturoids, the Lyomeri and the ceratioid angler fishes are able to capture and master relatively large fishes, which may even be longer than themselves.

It is thus perfectly clear that these deep-sea predators are not handicapped by their relatively feeble muscular system. And, as we have seen, the main structures for holding and swallowing the prey, the jaws and gill arches, are supported by the most firmly ossified parts of the skeleton. Sections through the lower jaws of Gonostoma elongatum and Diaphus rafinesquei (a lantern fish with a capacious swimbladder) showed that the degree of ossification was much the same, but that the bone was thinner in the former. (This fish has a standard length of $205 \mathrm{~mm}$ and a lower jaw length of $36 \mathrm{~mm}$, the bone of the latter having a maximum thickness of $0.03 \mathrm{~mm}$. The corresponding measurements in the lantern fish are, 74, I6 and $0.12 \mathrm{~mm}$ ). However, just beneath the toothbearing surface of the lower jaw and continuing to the angle, the bone in the gonostomatid has a honeycomb-like structure, which must give extra strength along the biting edge.

${ }^{1}$ Judging from trawl catches, a number of species appear to live close to the deep sea floor. 
But while the jaws and associated structures have a relatively robust framework, the fish (or squid) has first to be caught. Observations on the capture of large prey have yet to be made, although both Mackintosh and Gunther (Clarke, 1950) watched a silvery stomiatoid fish attacking a swarm of krill at the surface. Gunther wrote: 'In its manner of lurking and snapping prey it resembled the freshwater pike.' Beebe \& Crane (1939) observed that melanostomiatid fishes brought up alive '...swam about and snapped with all the accuracy of balance and swiftness of surface fish'.

However, fishes with thin lateral myotomes are hardly fitted to be tireless hunters, and this is borne out by their body forms and fin patterns. Like the pike, or better still the garfishes (Belonidae), the melanostomiatids, stomiatids and malacosteids have slim, elongated bodies and the dorsal and anal fins are opposed and set well back, close to the caudal fin. As in the species that Gunther saw, they are fishes which hover and dart after their prey. The combined dorsal, anal and caudal fins must form a powerful swimming organ (Beebe \& Crane, 1939). Even more important, this fin arrangement will not only enable the fish to get away quickly from a hovering position but also confer stability during the dart (see Harris, 1952).

Dr S. Smith has noted from the radiographs that the myotomes are of relatively constant width along the length of the fish. We may compare the rapidly diminishing width of myotome on moving close to the tail of Gadus minutus with the almost constant width of myotome of the deep sea fish. The deep sea fish have not therefore flexible tails adapted for delicate movements.

The alepisauroids also tend to have an elongated pike-like form (the paralepidids are known as barracudinas), but only the anal fin has a posterior setting. One species, Paralepis rissoi, was observed from a bathyscaphe by Furnestin (1955), who describes it as hovering in a vertical position with the head or tail uppermost, apparently keeping its level by the flickering of the small dorsal fin. Then, from this position, the fish would suddenly 'jack-knife' and dart off. At least some of the other paralepidids may be expected to behave in a similar way, while a hovering-darting habit is likely to be common to all alepisauroids. ${ }^{1}$

The ceratioid angler-fishes achieve even greater economy of effort by luring their prey to within striking distance (Bertelsen, I95I). They are clearly floating traps par excellence. Brauer (1908) thought that the luminous chin barbels of stomiatoid fishes might also be used as lures, while in Chauliodus the long second ray of the dorsal fin, which is tipped with luminous tissue, also appears to be an angling device (Tchernavin, 1953). Some of the stomiatoids even have light organs within the mouth. It is also conceivable that the spongy luminous tissue on the tail of the gulper-eel, Saccopharynx, may also act as a lure.

1 The scopelarchids and evermannellids have upwardly directed, tubular eyes and thus might be expected to adopt a horizontal position when hovering. 
Lastly, it should be emphasized that these fishes live in the quieter parts of the ocean under the thermocline, which has an average depth of about $75 \mathrm{~m}$. Above the thermocline the currents are relatively fast and wind-driven; below this level the (density) currents are more sluggish and the water is much less turbulent. In these deeper reaches a fish with relatively reduced propulsive powers can use these to greater effect (during a sudden dart) than under more boisterous conditions.

To summarize, bathypelagic fishes without a swimbladder often radically reduce their weight in water by developing lightly ossified skeletons, which are associated with reduced muscular systems, particularly along the trunk and tail. ${ }^{1}$ In spite of this many of them are able to capture and swallow large prey. However we must add that this tendency is not invariable among such predacious fishes. Certain of the Astronesthidae and Chiasmodon (the great swallower) have well developed swimbladders (together with firm skeletons and fairly thick lateral myotomes). A closer comparison between these bathypelagic fishes and those without a swimbaldder would clearly be interesting.

We should like to thank Mr G. Parish for advice and help with the radiography, and Captain C. A. Hoodless and the crew of R.V. 'Sarsia' for their co-operation. We are grateful to $\mathrm{Mr} \mathrm{R}$. G. Maddock for excellent technical assistance.

\section{SUMMARY}

Gonostoma elongatum is often within $0.5 \%$, and Xenodermichthys copei within $\mathrm{I} \cdot 2 \%$, of neutral buoyancy despite the fact that neither of these fish has a gas-filled swimbladder.

The dry weights of Gonostoma elongatum and Xenodermichthys copei are only about 12.6 and I0 \% of their wet weights compared with $28 \%$ for a typical coastal marine fish Ctenolabrus rupestris.

The fat content of Gonostoma elongatum and Xenodermichthys copei is not particularly high, averaging about $3 \%$ of their wet weight, but their protein content which is only about $4-7 \%$ of their wet weight is very low indeed when compared with the corresponding $16 \%$ for a typical coastal marine fish.

Radiographs of Gonostoma elongatum, Xenodermichthys copei and Chauliodus sloanei show that their skeletons are poorly ossified when compared with that of Gadus minutus a typical coastal marine fish of the same size, whereas the skeleton of Diaphus rafinesquii is ossified as well as that of Ctenolabrus rupestris a coastal marine fish of similar size. The skeleton of Gonostoma

${ }^{1}$ It is difficult to imagine a much weaker skeleton without much weaker muscles for, as A. V. Hill (1950) writes: 'Athletic animals in fact, have rather a small factor of safety... if a man's muscles could be altered without altering his general design, so as to allow him to run $25 \%$ faster or jump $50 \%$ higher, athletics would become a highly dangerous pastime; pulled tendons, torn muscles, even damaged bones, would be so frequent as to make it prohibitive.' 
denudatum, a bathypelagic fish with a swimbladder, is shown to be very well ossified in contrast with that of the related species Gonostoma elongatum.

The ash of Xenodermichthys was found to be about $\mathrm{I} \cdot 5 \%$ of the wet body weight, whilst that of Ctenolabrus rupestris was about $4.5 \%$.

The 'design' of these fish in relation to the life they lead is discussed. The muscular system is particularly reduced along the trunk and tail; whilst the jaws and gill arches, the main structures for holding and swallowing their prey, are supported by the most firmly ossified parts of the skeleton. These fish are almost certainly not tireless hunters, but rely on quick darts, often using luminous lures to attract their prey. Many of them could be simply described as floating traps.

\section{REFERENCES}

Beebe, W. \& Crane, J., I939. Deep sea fishes of the Bermuda Oceanographic Expeditions. Family Melanostomiatidae. Zoologica, N.Y., Vol. 24, pp. 65-238.

Bertelsen, E., I95I. The Ceratioid fishes. Dana Rep. (Vol. 7), No. 39, I84 pp.

Bertelsen, E. \& Marshall, N. B., I956. The Miripinnati, a new order of teleost fishes. Dana Rep. (Vol. 8), No. 42, 34 pp. Copenhagen.

Brauer, A. (1908). Die Tiefsee-fische. II. Anatomischer Teil. Wiss. Ergebn. Valdivia, Bd. 15, Lf. 2, 266 pp.

Clarke, R. I950. The bathypelagic angler fish Ceratias holbölli Kröyer. Discovery Rep., Vol. 26, pp. I-32.

Cooper, L. H. N., I952. The physical and chemical oceanography of the waters bathing the Continental Slope of the Celtic Sea. F. mar. biol. Ass. U.K., Vol. 30, pp. $465-5$ Io.

Furnestin, J. 1955. Une plongée en bathyscaphe. Rev. Trav. Pêches marit., T. I9, No. 4 , pp. 435-42.

Gray, J., 1953. The locomotion of fishes. Essays in Marine Biology, pp. I-I6. Edinburgh: Oliver and Boyd.

GreY, M., I956. The distribution of fishes found below a depth of 2000 metres. Fieldiana, Zool., Vol. 36, (No. 2), pp. 75-337.

Handbook of Biological Data (1956). Editor: W. S. Spector. Ohio, U.S.A.: Wright Air Development Centre.

HARRIS, J. E., I952. Fin patterns and mode of life in fishes. Essays in Marine Biology, pp. 17-28. Edinburgh: Oliver and Boyd.

HaRrow, B., I945. Text-book of Biochemistry. Philadelphia: W. Saunders.

HILl, A. V., 1950. The dimensions of animals and their muscular dynamics. Sci. Progr. Twent. Cent., Vol. 38, No. 150, pp. 209-30.

HöBER, R., 1945. Physical Chemistry of Cells and Tissues. London: Churchill.

International Critical Tables of Numerical Data Physics, Chemistry and Technology, 1928. Vol. 3, New York: McGraw Hill.

Jones, F. R. H. \& MARShall, N. B., I953. The structure and functions of the teleostean swimbladder. Biol. Rev., Vol. 28, pp. 16-83.

KANwiSher, J. \& Ebeling, A., I957. Composition of the swimbladder gas in bathypelagic fishes. Deep-Sea Res., Vol. 4, pp. 2 II-I7.

KeRMACK, K. A., I948. The propulsive powers of blue and fin whales. F. exp. Biol., Vol. 25, pp. 237-40.

Krogh, A., 1939. Osmotic Regulation in Aquatic Animals. Cambridge University Press. 
Love, R. M., 1957. The Biochemical Composition of Fish. In The Physiology of Fishes, Vol. I, edited by Margaret E. Brown, pp. 40I-I8. New York: Academic Press.

Lovern, J. A., 1955. The Chemistry of Lipids of Biochemical Significance. London: Methuen.

Marshall, N. B., I954. Aspects of Deep Sea Biology. London: Hutchinsons.

— 1955. Alepisauroid fishes. 'Discovery' Rep., Vol. 27, pp. 303-36. (in preparation). The swimbladders of deep sea fishes.

Nusbaum-HILARowicz, J., I923. Études d'anatomie comparée sur les poissons provenant des compagnes scientifiques de S.A.S. le Prince de Monaco. Résult. Camp. sci. Monaco, Fasc. 65, pp. I-100.

SHEWAN, J. M., I95I. The chemistry and metabolism of the nitrogenous extractives in fish. Symp. biochem. Soc., No. 6, pp. 28-48. Cambridge University Press.

TChernavin, V. V., I947. Six specimens of Lyomeri in the British Museum (with notes on the skeleton of Lyomeri). F. Linn. Soc. (Zool.), Vol. 4I, pp. 287-350.

— 1953. The Feeding Mechanisms of a Deep Sea Fish Chauliodus sloanei Schneider, viii + Ior pp. London: British Museum (Nat. Hist).

Vinogradov, A. P., I953. The Elementary Composition of Marine Organisms. (Efron and Stlow, translators). New Haven: Yale University Press. 